\title{
[Research Article]
}

\section{CORRELATION OF SYMBOLIC LANGUAGE AND CAUSE AND EFFECT RELATIONSHIP TO MATHEMATIC MODELING IN SENIOR HIGH SCHOOL PHYSICS LESSONS}

\author{
Desy Kumala Sari' and Pri Ariadi Cahya Dinata ${ }^{2}$ \\ 1Physics Education Department, Faculty of Teacher Training and Education, Universitas \\ Musamus, Merauke, Indonesia \\ ${ }^{2}$ Physics Education Department, Faculty of Teacher Training and Education, Universitas \\ Palangka Raya, Palangkaraya, Indonesia \\ E-mail: sarifkip@unmus.ac.id
}

DOI: https://doi.org/10.15575/jotalp.v7i1.11009

Received: 21 January 2021 ; Accepted: 1 November 2021 ; Published: 28 February 2021

\begin{abstract}
The generic science skills are the fundamental abilities that must be possessed by every student who studies science. This ability consists of direct observation, indirect observation, symbolic language, logical inference, causal relations, mathematical modelling, and construct concepts. This study only focused on indicators of symbolic language, causal relationships, and mathematical modelling. This research is a correlation study that aims to determine the relationship between symbolic language abilities and causal relationships on mathematical modelling abilities in physics subjects. The study results indicate a 'sufficient' relationship between symbolic language abilities and causal relationships to mathematical modelling abilities in physics subjects. Suggestions for further researchers are that the learning process should focus on the science process, which needs to guide students to develop their generic abilities in science, especially physics.
\end{abstract}

Keywords: generic science skills, symbolic language, causal relationships, mathematical modelling

How to cite: Sari, D. K. \& Dinata, P. A. C. (2022). Correlation of symbolic language and cause and effect relationship to mathematic modeling in senior high school physics lessons, Journal of Teaching and Learning Physics 7 (1), 54-61. DOI: https://doi.org/10.15575/jotalp.v7i1.11009 



\section{INTRODUCTION}

The purpose of education is to build or form humans who know. Through the knowledge possessed by each individual, it is hoped that it can change the mindset and human skills for the better (Bahri et al., 2020). Following the National Long-Term Development Plan from 2005 to 2025, education is directed to respond to globalization and the needs of national development in order to increase the nation's competitiveness. Therefore, education in Indonesia must be directed to meet the needs of national development (D. K. Sari et al., 2018) in the era of the industrial revolution 4.0 .

Education and curriculum have a very close relationship. The quality of education depends on the curriculum applied (Widodo \& Sriyono, 2020). Therefore, the two are inseparable. The presence of the 2013 curriculum is a solution to meet educational needs in this era (Sartika, 2019; Davidi, 2021). The approach to the 2013 curriculum is more complex than the previous curriculum applicable in Indonesia based on the creativity of students (Dinata et al., 2020). So that students are trained in their skills in solving various problems.

Concerning the importance of skills in learning physics apart from aiming at building knowledge, learning physics also basically involves the active activities of students to build basic abilities/skills for scientific work (Agustin et al., 2019; Lestari et al, 2018). For example, in the physics learning process, students are expected to conduct experiments (practicum) and understand the generic abilities of existing science. As a teacher, it is deemed necessary to prepare students to develop basic thinking patterns towards higher thinking patterns (D. Sari et al., 2019; Sutarno, 2011).

This mindset is not considered seriously by the teacher because of the ignorance factor. Under the results of observations in several high schools in Kupang City, the way teachers teach science material, especially physics, only focuses on memorizing concepts, memorizing formulas and practising math problems. This problem is the cause of the low quality of learning. In line with that, the Program for International Student Assessment (PISA) survey in 2018 showed that the results of the analysis of science scores for Indonesia were 396 (OECD, 2018). This result shows a decrease compared to 2015, 403 (OECD, 2015). These facts are essential homework for the government and education practitioners in improving students' scientific literacy in Indonesia. It should be noted that the characteristics of the questions tested in the PISA program tend to focus on aspects of reasoning and problem solving, which are closely related to the students' generic science abilities. However, science, especially physics, only emphasizes the mastery of procedural basic counting skills in Indonesia.

One solution that can help students train basic thinking skills is using and developing indicators of generic science skills (Sutarno, 2011). Examples of generic ability indicators (Brotosiswoyo., 2000) that characterize physics lessons are direct observation, indirect observation, symbolic language, logical inference, causal relationships, mathematical modelling, and concept building.

Symbolic language ability expresses natural behaviour that cannot be explained by everyday language but uses certain symbols (Pujani, 2018; Zakwandi, 2020) or is associated with specific events (Lämsä, 2018; Yulkifli et al, 2019). For example, in Newton's second law, acceleration is symbolized by the letter a, which comes from the word "acceleration", which means acceleration (Dinata et al., 2018; Baihaqi et al., 2021). Indicators of symbolic language skills used include understanding the quantitative meaning of units and quantities from equations and reading graphs/diagrams, tables, and mathematical signs. For this type of symbolic language ability, researchers measure students' ability by using a test instrument in the form of an objective test that contains the concept of symbolic language in physics subjects. 
The ability of a causal relationship is a type of thought that begins with an event that is considered a factor is causing another event (Mashami \& Khaeruman, 2020; P.A.C. Dinata \& Suparwoto, 2018; Pujani, 2015). For example, Newton's second law is deduced from empirical observations that if there is a force $\mathrm{F}$ acting on an object of mass $m$, there will be an acceleration proportional to the force, and its direction is in the direction of the force. The indicators used by researchers on the ability of causal relationships include stating the relationship between two or more variables in a particular natural phenomenon and estimating the causes of natural phenomena. For this type of causal relationship ability, researchers measure students' ability by using an instrument in the form of objective test questions that contain the concept of a causal relationship in physics subjects.

Mathematical modelling ability represents realworld or situational problems both in a qualitative and quantitative form, which can be expressed in the form of graphs or formulas in the form of equations (Desy Kumala Sari, 2020; Yusup, 2012). For example, Newton's second law equation can be formulated in the form of the equation $a=\frac{\sum F}{m}$, where a is the acceleration, $\mathrm{F}$ is the force and $m$ is the mass of the object. The indicators used by researchers on mathematical modelling abilities include revealing natural phenomena/problems in sketches/graphics and revealing natural phenomena in formulations. For this type of mathematical modelling ability, researchers measure students' abilities by using an instrument in the form of objective test questions that contain mathematical modelling concepts in physics subjects.

It is necessary to know the relationship of each indicator to increase the generic ability of science students in Indonesia to be more leveraged. Therefore, this research is focused on knowing the relationship between symbolic language skills and the causal relationship to mathematical modelling in high school physics subjects. The assumptions and limitations of this study are that the implementation of the teaching and learning process for physics in schools runs according to the applicable curriculum, and students follow all processes that are carried out seriously so that the results of this study genuinely reflect the abilities of students.

\section{METHOD}

This research includes quantitative research with a correlation method. This research was conducted in Kupang City with a population of all high school students. Respondents involved in this study were taken using a purposive sampling technique from 5 (five) high schools scattered in the city's downtown and the city's outskirts. The research data were analyzed using a linear regression test and correlation analysis using SPSS software. The interpretation of the correlation coefficient (Sugiono, 2007) used in this study is presented in Table 1.

Table 1. Interpretation of correlation coefficient

\begin{tabular}{cc}
\hline $\begin{array}{c}\text { Correlation Coefficient } \\
\text { Interval }\end{array}$ & Interpretation \\
\hline $0.00-0.199$ & Very low \\
\hline $0.20-0.399$ & Low \\
\hline $0.40-0.599$ & Enough \\
\hline $0.60-0.799$ & High \\
\hline $0.80-1.000$ & Very high \\
\hline
\end{tabular}

\section{RESULT AND DISCUSSION}

The research was carried out in 5 (five) public high schools in Kupang. This research was conducted by providing an assessment instrument to measure the ability of symbolic language, causal relationships, and mathematical modelling. The overall instrument consists of 45 questions, each of which consists of 15 questions to measure symbolic language skills, causal relationships, and mathematical modelling. The form of the questions given is multiple-choice, with the time given for processing the questions for 90 minutes or the equivalent of 2 hours of lessons. The research data were then analyzed using regression and correlation tests. The results 
of simple correlation analysis between variables are presented in Table 2.

Table 2. Results of simple correlation analysis between variables

\begin{tabular}{lccccccc}
\hline \multicolumn{1}{c}{ Correlation } & $\mathrm{r}$ & $\mathrm{a}$ & $\mathrm{b}$ & $\mathrm{t}_{\text {test }}$ & $\mathrm{Sig}$. & $\mathrm{R}_{\text {square }}$ & $\mathrm{F}_{\text {count }}$ \\
\hline $\begin{array}{l}\text { Symbolic Languages -Mathematical } \\
\text { Modeling }\end{array}$ & $0.558^{* *}$ & 16.426 & 0.411 & 6.921 & 0.000 & 0.311 & 47.907 \\
$\begin{array}{l}\text { Cause and Effect Relationships - } \\
\text { Mathematical Modeling }\end{array}$ & $0.255^{* *}$ & 25.402 & 0.290 & 2.72 & 0.008 & 0.065 & 7.401 \\
\hline
\end{tabular}

Based on the analysis results between symbolic language skills and mathematical modelling, the average score for symbolic language skills was 42.37, while the average score for mathematical modelling was 35.12. Based on Table 2, the information obtained is in the form of a correlation coefficient between symbolic language skills and mathematical modelling, namely, $\mathrm{r}=0.558$ with ${ }^{* *}$. With a value $=16,426$ and $a$ value of $b=0.441$. The value of $t_{\text {tes }}=6921$ with a significance of 0.000 . The coefficient of determination is 0.311 , and the $F_{\text {count }}$ value is 47.907.
Furthermore, the analysis results of the ability of causal relationships to mathematical modelling obtained an average value for the ability of causal relationships of 33.54. Under Table 2, the correlation coefficient between the ability of causal relationships and mathematical modelling is $\mathrm{r}=0.255$ with $\mathrm{a}^{* *}$. The a value obtained is 25,402 , while the $b$ value is 0.290 . The t-test value obtained is 2.72 with a significance of 0.008 . Also, the coefficient of determination is 0.065 , with the obtained $\mathrm{F}_{\text {count }}$ value of 7.401.

Table 3. Results of multiple correlation analysis between variables

\begin{tabular}{|c|c|c|c|c|c|c|c|c|}
\hline Correlation & $\mathrm{R}$ & $\mathrm{a}$ & $b_{1}$ & $\mathrm{~b}_{2}$ & $\mathrm{t}_{\text {test }}$ & Sig. & $\mathrm{R}_{\text {square }}$ & $F_{\text {count }}$ \\
\hline $\begin{array}{l}\text { Symbolic Language and Cause- } \\
\text { Effect Relationships - } \\
\text { Mathematical Modeling }\end{array}$ & 0.558 & 16.426 & 0.440 & 0.004 & 6.124 & 0.000 & 0.311 & 23.728 \\
\hline
\end{tabular}

The results of the multiple correlation analysis between symbolic language abilities and causal relationships are presented in Table 2. The information obtained is, the value of the multiple correlation coefficient is $\mathrm{R}=0.558$. With the value of $\mathrm{a}=16,426$, the value of $\mathrm{b} 1=0.440$, and the value of $b 2=0.004$. The value of $t_{\text {tes }}=6.124$ with a significance of 0.000 . The coefficient of determination is 0.311 , and $F_{\text {count }}$ is 23,728 .

Students in each school have different cognitive abilities, especially their generic science abilities. The generic ability of science is an ability or skill that makes an impression on students' minds. Therefore, the generic ability of science in each student must be different. Based on the results of research in the city of Kupang, it was found that there was a relationship between the ability of students to understand symbolic language and a causal relationship to mathematical modelling in physics subjects.

Based on Table 2, the correlation coefficient between symbolic language skills and mathematical modelling is $r=0.558$ or $55.8 \%$, in the 'sufficient' category. This result occurs because of the lack of understanding of students' understanding of symbols, symbols, and terms in physics subjects and the inability of students to read graphs/diagrams, tables, and mathematical signs correctly. In addition, based on the secondary data obtained, questions of symbolic language types are more often given to students as an exercise or in UTS activities so that students are more familiar with or easier to understand symbolic language type questions. In addition, discussing physics is closely related to symbols, in this case, symbolic language. So, before studying physics subjects further, students must first be 
taught the symbols used in physics. These symbols are referred to as symbolic language in physics subjects. Although students are more familiar with symbolic language questions, the relationship between symbolic language skills and mathematical modelling abilities is still in the 'enough' category. Teachers can provide students with an understanding of symbolic language in high school physics material.

The regression equation obtained in this relationship is $\hat{Y}=16.426+0.441 X_{1}$ so that it is known that the regression direction coefficient (b) is positive, which means there is an increase. So that it can be explained that every time the $\mathrm{X}_{1}$ variable (symbolic language ability) increases by one, the average value of the $\mathrm{Y}$ variable (mathematical modelling ability) increases by 0.441 . If the $X_{1}$ variable is known to be equal to 1 , the interpretation value can be estimated by entering the of $\hat{Y}=16.867$ is obtained. This $Y$ value shows the significance between symbolic language skills and mathematical modelling abilities.

The coefficient of determination is 0.311 , which means that the influence of the independent variable on changes in the dependent variable is $31.1 \%$, while $68.9 \%$ is influenced by variables other than symbolic language ability. So, it can be seen that the effect of students' symbolic language skills on increasing mathematical modelling skills is only $31.1 \%$ of the $100 \%$ percentage for all indicators of science generic ability in high school physics subjects. From the calculation results, the value of $t_{\text {tes }}=6.921$ with a significance of 0.000 . That value is smaller than 0.05 , and $H_{o}$ is rejected. It means that there is an influence of the symbolic language ability variable on the mathematical modelling ability. For the value of $F_{\text {count }}=47.907$ dan $F_{\text {table }}=3.93$. Because $F_{\text {count }}>F_{\text {table }}$, which is $47.907>3.93$, there is a significance between symbolic language skills and mathematical modelling.

Based on the linear regression test results, the correlation coefficient between the ability of the causal relationship and mathematical modeling was obtained, namely, $\mathrm{r}=0.255$ or $25.5 \%$, which was in the low category. The low relationship between causality and mathematical modelling abilities is probably due to the lack of students' understanding of the relationship between several variables in a particular natural phenomenon. Students have also not been able to estimate the cause of a natural phenomenon. In addition, from secondary data obtained, questions on the type of causal relationship were not tested at all in the midterm exam. It makes it possible that students are not familiar with the types of causal relationships the researcher gives. The ability of causal relationships is an essential ability that students should first understand to determine the mathematical model correctly.

In addition, the regression equation obtained is $\hat{Y}=25.402+0.290 X_{2}$ o that it is known that the regression direction coefficient (b) is positive, which means there is an increase. So that it can be explained that every time the $X_{2}$ variable (causational ability) increases by one, the average value of the $Y$ variable (mathematical modelling ability) increases by 0.290 . If the variable $X_{2}$ is known to be equal to 1 , then $\hat{Y}=25.692$. The coefficient of determination is 0.065 , which means that the influence of the independent variable on changes in the dependent variable is $6.5 \%$, while $93.5 \%$ is influenced by variables other than symbolic language ability. So, it can be seen that the effect of students' causal relationship skills on increasing mathematical modelling abilities is only $6.5 \%$ of the $100 \%$ for all indicators of generic science ability in high school physics subjects. From the results of this calculation, it can be seen that increasing the ability of causal relationships has a negligible effect on increasing mathematical modelling abilities.

The value of $t_{t e s}=2.720$ with a significance of 0.008 is smaller than 0.05 . Thus, Ho is rejected, which means that the symbolic language ability variable influences the mathematical modelling ability. The value of $F_{\text {count }}$ was obtained at 7.401, while $F_{\text {table }}$ was 3.93 . Because $F_{\text {count }}>F_{\text {table }}$, which is $7.401>3.93$, it can be concluded that there is a 
significance between symbolic language skills and mathematical modelling. Based on the analysis results, the correlation coefficient between symbolic language ability and causal relationship to mathematical modelling ability is $\mathrm{R}=0.558$ or $55.8 \%$, which is sufficient. From the calculation of multiple correlations, it can be seen that the value of the multiple correlations between symbolic language ability and the causal relationship to mathematical modelling ability is the same as the correlation coefficient between symbolic language ability and mathematical modelling ability.

For the regression equation, it is obtained that $\hat{Y}=16.346+0.440 X_{1}+0.004 X_{2}$ which means that every 1 unit increase in $X_{1}$ variable will increase the value of the $Y$ variable by 0.440 units with the assumption that other variables have a fixed value and every 1 unit increase in $X_{2}$ variable will increase the value variable $Y$ is 0.004 units with the assumption that other variables have a fixed value. From the regression equation obtained, it can be concluded that the ability of symbolic language has a more significant influence on mathematical modelling than the ability of causal relationships. It is indicated that the acquisition of the value of $b_{1}$ is more significant than $b_{2}$.

The coefficient of determination obtained is 0.311 , meaning that the influence of the independent variable, in this case, is symbolic language ability and the causal relationship to changes in the dependent variable, namely mathematical modelling ability, is $31.1 \%$. In comparison, $68.9 \%$ is influenced by other variables besides symbolic language ability and causal relationships. From the significant coefficient of determination for these multiple correlations, it is obtained that the coefficient of determination is as significant as the coefficient of determination in the correlation between symbolic language skills and mathematical modelling abilities. It proves that the ability of symbolic language has a more significant influence than the ability of a causal relationship to mathematical modelling. The value of $F_{\text {count }}$ is
23.728 , and $F_{\text {table }}$ is 3.93 . Because $F_{\text {count }}>F_{\text {table, }}$, it can be concluded that there is a significance between symbolic language ability and a causal relationship to mathematical modelling.

Although in the UTS questions given to students, there are only types of questions that practice symbolic language skills and mathematical modelling, there is a significant relationship between symbolic language skills and a causal relationship to mathematical modelling abilities in high school physics subjects. To master a physics material gradually, a teacher must first understand the symbolic language contained in a physics material. Then give students an understanding of the causal relationship that applies to a particular physical event. After the two indicators are understood, students can correctly determine the mathematical modeling of a physics material.

\section{CONCLUSION}

This study concludes a relationship between symbolic language skills and mathematical modelling in the 'sufficient' category. At the same time, the relationship between the ability of causal relationships and mathematical modelling is in the 'low' category. Taken together, the relationship between symbolic language skills and the causal relationship to mathematical modelling abilities is in the 'enough' category. Suggestions for further researchers are that it is better to focus on the science process in the learning process, where it is necessary to guide students to develop their generic science skills, especially physics.

\section{REFERENCES}

Agustin, I., Amin, A., \& Arini, W. (2019). Penerapan pendekatan scientific terhadap aktivitas belajar fisika siswa kelas X SMA Negeri 3 Lubuklinggau tahun pelajaran 2018/2019. Silampari Jurnal Pendidikan Ilmu Fisika, 1(2),

121-129. https://doi.org/10.31540/sjpif.v1i2.793

Bahri, S., Rahayu, M., Sari, D. K., \& Simbolon, M. 
(2020). Analysis of information and communication technology literacy capabilities to the high school physics teacher in Merauke. Gravity: Jurnal Ilmiah Penelitian Dan Pembelajaran Fisika, 6(1), 47-53.

https://doi.org/10.30870/gravity.v6i1.63 65

Baihaqi, H. K., Jumadi, J., \& Zakwandi, R. (2021). Seeing the Role of PCK and TPACK from the Perspective of Science Education Researchers in 2018-2020: What's Next?. Jurnal Pendidikan Sains (JPS), 9(2), 171180.

https://doi.org/10.26714/jps.9.2.2021.17 $1-180$

Brotosiswoyo., B. S. (2000). Hakekat pembelajaran fisika di perguruan tinggi. Departemen Pendidikan Nasonal.

Davidi, E. I. N., Sennen, E., \& Supardi, K. (2021). Integrasi pendekatan stem (science, technology, enggeenering and mathematic) untuk peningkatan keterampilan berpikir kritis siswa sekolah dasar. Scholaria: jurnal pendidikan dan kebudayaan, 11(1), 11-22. https://doi.org/10.24246/j.js.2021.v11.i1. p11-22

Dinata, P. A.C., Rahzianta, R., \& Suparwoto, S. (2018). The Students' Mental Model about Newton's Third Law In Indonesia. Unnes Science Education Journal, 7(2). https://doi.org/10.15294/usej.v7i2.23366

Dinata, P. A. C., Suparwoto, S., \& Sari, D. K. (2020). Problem-based online learning assissted by whatsapp to facilitate the scientific learning of 2013 Curriculum. Berkala Ilmiah Pendidikan Fisika, 8(1), 1-11. https://doi.org/10.20527/bipf.v8i1.7647

Dinata, P.A.C., \& Suparwoto, S. (2018). Problembased learning with jukung and balogo to improve students' mental model in south borneo. Journal of Physics: Conference Series, 1097(1), 012026. https://doi.org/10.1088/17426596/1097/1/012026

Dinata, P. A. C., Rahzianta, R., \& Suparwoto, S. (2018). The Students' Mental Model about Newton's Third Law in Indonesia. Unnes
Science Education Journal, 7(2), 146-155. https://doi.org/10.15294/usej.v7i2.23366

Lämsä, J., Hämäläinen, R., Koskinen, P., \& Viiri, J. (2018). Visualising the temporal aspects of collaborative inquiry-based learning processes in technology-enhanced physics learning. International Journal of science education, $\quad \mathbf{4 0}(14)$, 1697-1717. https://doi.org/10.1080/09500693.2018. 1506594

Lestari, W. M., Ariani, T., \& Gumay, O. P. U. (2018). Pengembangan bahan ajar fisika berbasis scientific approach. SPEJ (Science and Physic Education Journal), 2(1), 18-29. https://doi.org/10.31539/spej.v2i1.435

Mashami, R. A., \& Khaeruman, K. (2020). Pengembangan Multimedia Interaktif Kimia Berbasis PBL (Problem Based Learning) untuk Meningkatkan Keterampilan Generik Sains Siswa. Hydrogen: Jurnal Kependidikan Kimia, 8(2), 85-96.

https://doi.org/10.33394/hjkk.v8i2.3138

OECD. (2016). PISA 2015 results in focus. PISA.

OECD. (2018). PISA 2018 Results. Combined Executive

Summaries. https://doi.org/10.1017/CB09781107415 324.004

Pujani, N. M. (2018). Pelatihan Pembuatan Alat Peraga Ilmu Pengetahuan Bumi Antariksa bagi Kelompok Guru SMP dan SMA Lab. Undiksha Singaraja. International Journal of Community Service Learning, 2(1), 1-9. http://dx.doi.org/10.23887/ijcsl.v2i1.136 81

Sari, D. K., Supahar, S., \& Ralmugiz, U. (2018). The influence of android-based isomorphic physics (Forfis) application on analogical transfer and self-diagnosis skill of students at SMA Negeri 3 Kupang. Jurnal Pendidikan IPA Indonesia, 7(2), 154-161. https://doi.org/10.15294/jpii.v7i2.14268

Sari, D., Simbolon, M., \& Reski, A. (2019). Utilization Isomorphic Physics (FORFIS) Application to Improve Physics Analogical Transfer Skill of Senior High School Students. Proceedings of the International Conference on Social Science 2019 (ICSS 
2019). https://doi.org/10.2991/icss19.2019 .206

Sari, D K. (2020). Analisis instrumen penilaian kemampuan pemodelan matematis pada kelas fisika menggunakan rasch model. MEGA: Jurnal Pendidikan Matematika, 1(1), 46-52.

Sartika, D. (2019). Pentingnya pendidikan berbasis STEM dalam kurikulum 2013. Jurnal Ilmu Sosial Dan Pendidikan, 3(3), 8993.

http://dx.doi.org/10.36312/jisip.v3i3.797

Sugiono. (2007). Statistika untuk penelitian. CV. Alphabeta.

Sutarno. (2011). Penggunaan multimedia interaktif pada pembelajaran medan magnet untuk meningkatkan keterampilan generik sains mahasiswa. Jurnal Exacta, 9(1), 60-466.

Widodo, W., \& Sriyono, H. (2020). Strategi pemberdayaan guru dalam meningkatkan mutu pendidikan. Faktor Jurnal Ilmiah Kependidikan, 7(1), 7-12. http://dx.doi.org/10.30998/fjik.v7i1.5628

Yulkifli, Y., Ningrum, M. V., \& Indrasari, W. (2019). The validity of student worksheet using inquiry-based learning model with science process skill approach for physics learning of high school. Jurnal Penelitian \& Pengembangan Pendidikan Fisika, 5(2), 155-162. https://doi.org/10.21009/1.05210

Yusup, M. (2013). Pendekatan pemodelan matematis dalam pembelajaran fisika. Jurnal Penelitian Pendidikan. 1-5

Zakwandi, R., Yuningsih, E. K., \& Setya, W. (2020). Implementasi Pembelajaran Berbasis Praktikum Pada Konsep Taraf Intensitas Bunyi untuk Meningkatkan Penguasaan Konsep Peserta Didik. Jurnal Penelitian Pembelajaran Fisika, 11(1), 75-82. https://doi.org/10.26877/jp2f.v11i1.4522 